\title{
STRES KERJA PERAWAT DIRUANG RAWAT INAP RSUD H. A. SULTHAN DAENG RADJA KABUPATEN BULUKUMBA
}

\author{
${ }^{1}$ Nur Awaliya Hasbi \\ ${ }^{2}$ Fatmawati \\ ${ }^{3}$ Nadia Alfira
}

\begin{abstract}
IProgram Studi S1 Keperawatan Stikes Panrita Husada Bulukumba, Indonesia
2.Departemen Keperawatan Jiwa, Stikes Panrita Husada Bulukumba, Indonesia

${ }^{3}$ Departemen Keperawatan Medical Bedah, Stikes Panrita Husada Bulukumba, Indonesia
\end{abstract}

\begin{abstract}
Alamat Koresponden:
Nur Awaliya Hasbi

Barombong Kecamatan Gantarang

Kabupaten Bulukumba

Hp. 082344724402

Email: nurawaliyahasbi@yahoo.com
\end{abstract}




\begin{abstract}
ABSTRAK
Stres merupakan reaksi tubuh dan psikis terhadap tuntutan - tuntutan lingkungan terhadap seseorang. Stres kerja perawat adalah suatu kondisi dari hasil penghayatan subjektif individu yang dapat berupa interaksi antara individu dan lingkungan kerja yang dapat mengancam dan memberi tekanan secara psikologis, fisiologis dan perilaku perawat. Menurut hasil survei dari PPNI (Persatuan Perawat Nasional Indonesia) tahun 2015 menunjukkan bahwa $51 \%$ perawat mengalami stres dalam bekerja, lelah, kurang ramah, sering pusing, kurang istirahat akibat beban kerja yang tinggi dan penghasilan yang tidak memadai. Jika hal ini dibiarkan tentunya akan menimbulkan dampak yang lebih buruk. Dari hasil studi pendahuluan yang dilakukan peneliti didapatkan jumlah perawat diruang rawat inap yaitu 171 perawat yang tersebar dibeberapa ruangan. Tujuan penelitian ini adalah untuk mengetahui gambaran stres kerja perawat diruang rawat inap RSUD H. A. Sulthan Dg Radja Kabupaten Bulukumba. Penelitian ini menggunakan desain deskriptif dengan pendekatan survey cross sectional. Populasi dalam penelitian ini yaitu 171 orang. Sampel pada penelitian ini sebanyak 95 orang dengan metode pengambilan sampling menggunakan metode probability sampling dengan teknik pengambilan sampel menggunakan proportional stratified random sampling. Hasil penelitian yang didapatkan bahwa tingkat stres kerja perawat paling banyak pada tingkat stres ringan sebanyak 54 responden (56,8\%), sedangkan tingkat stres sedang sebanyak 41 responden $(43,2 \%)$. Kesimpulan dari penelitian ini adalah perawat diruang rawat inap RSUD H. A. Sulthan Dg Radja Kabupaten Bulukumba Tahun 2018 menunjukkan bahwa mayoritas perawat cenderung mengalami stress kerja pada tingkat ringan 84 responden $(88,4 \%)$. Disarankan bagi petugas kesehatan terutama perawat agar perlu melakukan manajemen stres yang efektif berupa teknik relaksasi, pengelolaan waktu, pemecahan masalah yang baik dan sebagainya.
\end{abstract}

\title{
Kata Kunci : Stres Kerja, Perawat, Relaksasi
}

\begin{abstract}
Stress is a physical and psychological reaction to environmental demands on a person. Nurse work stress is a condition of the results of an individual's subjective appreciation which can be in the form of interactions between individuals and the work environment that can threaten and stress psychologically, physiologically and nurses' behavior. According to a survey from the 2015 PPNI (Indonesian National Nurses Association), 51\% of nurses experienced stress at work, were tired, were not friendly, often had dizziness, lack of rest due to high workload and inadequate income. If this is left unchecked it will certainly have a worse impact. From the results of a preliminary study conducted by researchers, the number of nurses in the inpatient room is 171 nurses spread in several rooms. The purpose of this study was to determine the description of the work stress of nurses in the inpatient hospital of H. A. Sulthan Dg Radja Bulukumba Regency. This research uses descriptive design with cross sectional survey approach. The population in this study was 171 people. The sample in this study were 95 people with a sampling method using probability sampling method with sampling techniques using proportional stratified random sampling. The results of the study found that nurses work stress levels were most at mild stress levels of 54 respondents (56.8\%), while moderate stress levels were 41 respondents (43.2\%). The conclusion of this study is nurses in the inpatient hospital H. A. Sulthan Dg Radja Bulukumba Regency in 2018 shows that the majority of nurses tend to experience work stress at a mild level of 84 respondents (88.4\%). It is recommended for health workers, especially nurses to need to do effective stress management in the form of relaxation techniques, time management, good problem solving and so on.
\end{abstract}

Keywords: Job Stress, Nurse, Relaxation 


\section{PENDAHULUAN}

Stres merupakan reaksi tubuh dan psikis terhadap tuntutan - tuntutan lingkungan terhadap seseorang. Dalam bekerja orang kadang - kadang merasa tidak mampu, tertekan dan bosan, selain itu produktivitas atau prestasi kerja menurun sehingga akan memberikan dampak negatif terhadap unit kerja atau perusahaan tempat bekerja (Saam \& Wahyuni, 2014). Stres kerja perawat adalah suatu kondisi dari hasil penghayatan subjektif individu yang dapat berupa interaksi antara individu dan lingkungan kerja yang dapat mengancam dan memberi tekanan secara psikologis, fisiologis dan perilaku perawat (Wijono, 2014).

Menurut data WHO (Word Health Organisation) tahun 2015 penyakit yang ditimbulkan akibat kerja adalah depresi dibanyak Negara sebesar 8\%. Hasil penelitian labour force survey pada tahun 2016 menemukan adanya 440.000 kasus stres akibat kerja, diinggris angka kejadian sebanyak 1.380 kasus per 100.000 pekerja mengalami stres akibat kerja (Sari, 2016).

Menurut hasil survei dari PPNI (Persatuan Perawat Nasional Indonesia) tahun 2015 (dikutip dalam Vazia, 2016) menunjukkan bahwa $51 \%$ perawat mengalami stres dalam bekerja, lelah, kurang ramah, sering pusing, kurang istirahat akibat beban kerja yang tinggi dan penghasilan yang tidak memadai. Jika hal ini dibiarkan tentunya akan menimbulkan dampak yang lebih buruk. Menurut data Kementrian Kesehatan Republik Indonesia tahun 2016 jumlah perawat mencapai 296.876 orang, maka angka kejadian stres perawat cukup besar (Profil Kesehatan Indonesia, 2016).

Berdasarkan data dari Dinas Kesehatan Provinsi Sulawesi Selatan didapatkan jumlah tenaga keperawatan yang ada di rumah sakit yang berbeda pada tahun 2014 sebanyak 9,289 perawat, 2015 sebanyak 11,019 perawat dan 2016 sebanyak 11,005 perawat (Profil Kesehatan Provinsi Sulawesi Selatan, 2017).

Menurut Rekam Medis RSUD H A Sulthan Dg Radja Kabupaten Bulukumba dilakukan hasil pengumpulan data awal didapatkan jumlah perawat diruang rawat inap yaitu 171 perawat yang tersebar diruangan, 22 perawat diruangan paviliun, 22 perawat di ruangan mawar, 21 perawat diruangan perinatologi, 26 perawat diruangan melati, 27 perawat diruangan flamboyan, 4 perawat diruangan asoka, 19 perawat diruangan bougenvile dan 30 perawat diruangan seruni. Dari hasil wawancara yang telah dilakukan kepada 
pasien, ada beberapa pasien mengatakan bahwa selama dirawat di rumah sakit pelayanan yang didapatkan tidak sesuai dengan keinginannya karena perawat biasanya marah - marah , jutek, kurang ramah kepada pasien.

Dari hasil penelitian Hariyanti et al tahun 2013 tentang Hubungan Antara Beban Kerja Dengan Stres Kerja Perawat Diinstalasi Gawat Darurat RSUD Kabupaten Semarang, dengan metode penelitian yang digunakan adalah deskriptif korelasi, hasil penelitian yang didapatkan beban kerja sebagian besar perawat adalah tinggi sebanyak 27 responden $(93,1 \%)$, stres kerja perawat sebagian besar adalah stres sedang sabanyak 24 responden $(82,8 \%)$. Terdapat hubungan antara beban kerja dengan stres kerja perawat dimana $p$ value $0,000(\alpha$ : 0,05) dan didapatkan kesimpulan terdapat hubungan antara beban kerja dengan stres kerja perawat di RSUD Kabupaten Semarang.

Sedangkan hasil penelitian yang telah dilakukan Jundillah et al tahun 2017 tentang Analisis Kejadian Stres Kerja Pada Perawat Kamar Bedah Diinstalasi Bedah Sentral RSUD K.R.M.T Wongsonegoro Semarang, dengan metode penelitian yang digunakan adalah penelitian kuantitatif dengan desain cross - sectional, hasil penelitian yang didapatkan 17 perawat mengalami stres berat dan 66 perawat mengalami stres ringan, beban kerja $(p$ value $=0,002)$, kejenuhan $(p$ value $=$ 0,000), merupakan faktor penentu kejadian stres sedangkan faktor lingkungan ( $\rho$ value $=0,225)$ bukan merupakan faktor penentu kejadian stres kerja. Terdapat hubungan antara beban kerja dan kejenuhan kerja terhadap kejadian stres kerja pada perawat, tidak terdapat hubungan antara lingkungan kerja dengan kejadian stres kerja dan di dapatkan kesimpulan lebih banyak mengalami stres ringan, beban kerja berat, kejenuhan kerja, lingkungan kerja kurang baik terhadap kejadian stress kerja pada perawat di Kabupaten Konawe Kepulauan.

Tujuan penelitian ini adalah untuk mengetahui gambaran stres kerja perawat di ruang rawat inap RSUD H. A. Sulthan Dg Radja Kabupaten Bulukumba Tahun 2018.

\section{METODE}

Desain penelitian yang digunakan dalam penelitian ini adalah desain penelitian cross sectional (Setiawan \& saryono, 2010), yang bertujuan untuk mengetahui gambaran stres kerja perawat di ruang rawat inap RSUD H. A. Sulthan Dg Radja Kabupaten Bulukumba. 
Populasi adalah wilayah generalisasi yang terdiri atas objek / subjek yang mempunyai kuantitas dan karakteristik tertentu yang ditetapkan oleh peneliti untuk dipelajari dan kemudian ditarik kesimpulannya (Setiawan \& saryono, 2010) . Populasi dalam penelitian ini adalah semua perawat di ruang rawat inap RSUD H. A. Sulthan Dg Radja Kabupaten Bulukumba sebanyak 171 perawat.

Penarikan sampel menggunakan teknik proportional stratified random sampling dimana teknik ini di gunakan bila populasi mempunyai anggota/unsur yang tidak homogen dan berstrata secara proporsional (Haryono, Suryani, \& Wulandari, 2009). Jumlah sampel dalam penelitian ini adalah 95 perawat.

Instrumen yang digunakan dalam penelitian ini menggunakan lembar kuesioner. Kuesioner digunakan untuk mengumpulkan data tentang tingkat stres kerja perawat. Instrumen penelitian variabel stres kerja adalah lembar kuesioner yang dikutip dalam buku Nursalam.

Data dianalisis berdasarkan skala ukur dan tujuan penelitian dengan menggunakan perangkat lunak program komputerisasi. Data dianalisis secara analisis Univariat adalah analisis yang dilakukan untuk menganalisis variabel.

\section{HASIL}

Berdasarkan Tabel 1menunjukkan sebagian besar responden berjenis kelamin perempuan sebanyak 86 responden (90,5\%), sebagian besar responden berada pada kategori dewasa sebanyak 71 responden $(74,7 \%)$, sebagian besar responden berlatar belakang pendidikan S1+Ners sebanyak 56 responden $(58,9 \%)$, sebagian besar responden sudah menikah sebanyak 57 responden $(60,0 \%)$, sebagian responden mempunyai masa kerja <5 tahun sebanyak 57 responden $(60,0 \%)$.

Berdasarkan Tabel 2 menunjukkan bahwa ruangan seruni sebanyak 5 responden $(5,3 \%)$, ruangan flamboyan sebanyak 12 responden $(12,6 \%)$, ruangan boungfile sebanyak 11 responden $(11,6 \%)$, ruangan melati sebanyak 20 responden $(21,1 \%)$, ruangan isolasi sebanyak 11 responden (11,6\%), ruangan mawar sebanyak 20 responden $(21,1 \%)$ dan ruangan paviliun sebanyak 16 responden $(16,8 \%)$.

Berdasarkan Tabel 3 menunjukkan bahwa tingkat stress kerja perawat paling banyak pada tingkat stres ringan sebanyak 54 responden $(56,8 \%)$, sedangkan tingkat stres kerja sedang sebanyak 41 responden $(43,2 \%)$. 


\section{PEMBAHASAN}

Pada penelitian ini menunjukkan bahwa stres kerja perawat di ruang rawat inap RSUD H. A. Sulthan Dg Radja Kabupaten Bulukumba mayoritas adalah tingkat stres kerja ringan.

Hasil penelitian diatas sesuai dengan penelitian yang telah dilakukan oleh Sitorus \& Wulandari tahun 2015 dengan judul Gambaran Tingkat Stres Pada Perawat Diruang Rawat Inap Lantai 5 Blok C Rumah Sakit Umum Daerah Kota Jakarta Utara, dengan hasil penelitian yang didapatkan bahwa dari 25 responden mengalami stres kerja pada tingkat ringan.

Sedangkan penelitian yang telah dilakukan oleh Anggra Martina tahun 2012 dengan judul Gambaran Tingkat Stres Kerja Perawat Di Ruang Rawat Inap Rumah Sakit Paru Dr. Moehammad Goenawan Partowidigdo Cisarua Bogor (RSPG) dengan metode penelitian yang digunakan adalah penelitian deskriptif, dengan hasil penelitian yang didapatkan bahwa dari 80 perawat yang bekerja di ruang rawat inap RSPG Cisarua Bogor mengalami stres kerja pada tingkat sedang sebanyak 69 orang (86\%).

Peneliti berpendapat bahwa stres kerja yang dialami perawat cenderung dialami oleh perawat perempuan dibanding perawat laki - laki, karena rata
- rata perawat yang mengalami stres kerja adalah telah menikah dan mempunyai anak.

\section{KESIMPULAN DAN SARAN}

Berdasarkan hasil penelitian diatas maka disimpulkan bahwa perawat diruang rawat inap RSUD H. A. Sulthan Dg Radja Kabupaten Bulukumba tahun 2018 menunjukkan bahwa mayoritas perawat cenderung mengalami stres kerja pada tingkat ringan. Hasil penelitian semoga dapat digunakan sebagai bahan peningkatan wawasan dalam bidang penelitian serta menambah pengetahuan tentang gambaran stres kerja perawat diruang rawat inap

\section{DAFTAR PUSTAKA}

Barokah, \& Thoifatul. (2011, Juli). Faktorfaktor yang berhubungan dengan tingkat stres kerja perawat di Instalasi Gawat Darurat di RSUD.DR.Moewardi Surakarta.

Fitri, M. A. (2013). Analisis faktor yang berhubungan dengan kejadian stres kerja pada karyawan BANK . Jurnal kesehatan masyarakat .

Fuada, N., Wahyuni, I., \& Kurniawan, B. (2017). Faktor - faktor yang berhubungan dengan stres kerja pada perawat kamar bedah di Instalasi Bedah Sentral RSUD K.R.M.T Wongsonegoro 
Semarang. Jurnal kesehatan masyarakat .

Hakim, L., \& Sugiyanto, E. (2017). Manajemen stres kerja pengusaha untuk meningkatkan kinerja perusahaan di Industri Batik Laweyan Surakarta. Jurnal manajemen .

Hariyanti, Aini, F., \& Purwaningsih, P. (2013). Hubungan antara beban kerja dengan stres kerja perawat di instalasi gawat darurat RSUD Kabupaten Semarang. jurnal managemen keperawatan .

Haryono, W., Suryani, D., \& Wulandari, Y. (2009). Hubungan antara beban kerja, stres kerja dan tingkat konflik dengan kelelahan kerja perawat di Rumah Sakit Islam Yogyakarta PDHI Kota Yogyakarta. kesehatan masyarakat

Jundillah, Ahmad, \& Saktiansyah. (2017). Analisis kejadian stres kerja pada perawat di Kabupaten Konawe Kepulauan. Jimkesmas .

Martina, A. (2012). Gambaran Stres Kerja Perawat Di Rauang Rawat Inap Rumah Sakit Paru Dr.Moehammad Goenawan Partowidigdo Cisarua Bogor. Jurnal Manajemen Keperawatan

Mawengkang, Rattu, \& Umboh. (2014). Analisis faktor-faktor yang berhubungan dengan stres kerja perawat wanita di Instalasi Rawat Inap RSU Pancaran Kasih GMIM Manado. jurnal kesehatan .
Muchlas, M. (2012). Perilaku Organisasi. Yogyakarta: UGM Press.

Munandar, S. A. (2014). Psikologi Industri dan Organisasi. Jakarta: Universitas Indonesia Pres.

Nurazizah. (2017). Faktor - faktor yang berhubungan dengan stres kerja pada perawat diruang rawat inap kelas III RS X Jakarta. Kesehatan masyarakat .

Pofil Kesehatan Indonesia 2016, Profil Kesehatan Indonesia Tahun 2016. Kementrian Kesehatan Republik Indonesia. Diakses tanggal 14 Januari 2018.

Profil Kesehatan Provinsi Sulawesi Selatan 2017. Profil Kesehatan Provinsi Sulawesi Selatan Tahun 2017, Dinas Kesehatan Provinsi Sulawesi Selatan. Diakses tanggal 17 Januari 2018.

Rattu, Posangi, \& Thio. (2013). Hubungan antara stres kerja, iklim kerja, hubungan kerja dengan beban kerja perawat di Rawat Inap Rumah Sakit Bethesda GMIM Tomohon. jurnal kesehatan masyarakat .

Saam, Z., \& Wahyuni, S. (2014). Psikologi Keperawatan. Jakarta: PT RajaGrafindo.

Sari, R., Yusran, S., \& Ardiansyah, R. T. (2016). Faktor yang berhubungan dengan stres kerja pada perawat di Ruang Rawat Inap Rumah Sakit Jiwa Provinsi Sulawesi Tenggara. Jimkesmas . 
Setiawan, A., \& saryono. (2010). metodologi penelitian kebidanan DIII,DIV,S1 dan S2. yogyakarta: nuha medika.

Sitorus, E., \& Wulandari, S. (2015). Gambaran tingkat stres pada perawat diruang rawat inap lantai 5 Blok C Rumah Sakit Umum Daerah Kota Jakarta Utara. Jurnal Akademi Keperawatan Husada Karya Jaya .

Sugyono. (2014). Statistika untuk penelitian. Bandung: Alfabeta.

Suyanto. (2011). metodologi dan aplikasi penelitian keperawatan. yogyakarta: nuha medika.

Syamsuddin, Muriyati, Asnidar, \& Sumarmi. (2015). Pedoman Praktis Metodologi Penelitian Internal. Ponorogo: Wade Group.

Vazia. (2016). Hubungan konflik peran ganda dan dukungan sosial dengan stres kerja perawat pelaksana di Ruang Rawat Inap RSUD dr. Rasidin Padang. Jurnal kesehatan masyarakat .

Widyasari, J. K. (2013). Hubungan antara kelelahan kerja dengan stres kerja pada perawat di Rumah Sakit Islam Yarsis Surakarta. Jurnal Management .

Wijono, S. (2014). Psikologi Industri \& Organisasi. Jakarta: Kencana Prenada Media Group. 
Table 1

Distribusi karakteristik perawat diruang rawat inap RSUD H. A. Sulthan Dg Radja Kabupaten Bulukumba Tahun 2018

\begin{tabular}{|c|c|c|}
\hline Karakteristik & $\mathbf{F}$ & $\%$ \\
\hline \multicolumn{2}{|l|}{ Jenis Kelamin } & 9,5 \\
\hline Perempuan & 86 & 90,5 \\
\hline \multicolumn{3}{|l|}{ Umur } \\
\hline Remaja & 23 & 24,2 \\
\hline Dewasa & 71 & 74,7 \\
\hline Lansia & 1 & 1,1 \\
\hline \multicolumn{3}{|l|}{ Pendidikan } \\
\hline D3 & 36 & 37,9 \\
\hline S1+Ners & 56 & 58,9 \\
\hline $\mathrm{S} 2$ & 3 & 3,2 \\
\hline \multicolumn{3}{|c|}{ Status Perkawinan } \\
\hline Belum Kawin & 38 & 40,0 \\
\hline Kawin & 57 & 60,0 \\
\hline \multicolumn{3}{|l|}{ Lama Kerja } \\
\hline$<5$ Tahun & 57 & 60,0 \\
\hline 5-10 Tahun & 29 & 30,5 \\
\hline >10 Tahun & 9 & 9,5 \\
\hline Total & 95 & 100,0 \\
\hline
\end{tabular}


Table 2

Distribusi karakteristik ruangan rawat inap RSUD H. A. Sulthan Dg Radja Kabupaten Bulukumba

\begin{tabular}{lcc}
\hline Ruangan & F & \% \\
\hline Seruni & 5 & 5,3 \\
Flamboyan & 12 & 12,6 \\
Boungfile & 11 & 11,6 \\
Melati & 20 & 21,1 \\
Isolasi & 11 & 11,6 \\
Mawar & 20 & 21,1 \\
Paviliun & 16 & 16,8 \\
\hline Total & $\mathbf{9 5}$ & $\mathbf{1 0 0 , 0}$ \\
\hline
\end{tabular}

Table 3

Distribusi Frekuensi stres kerja perawat diruang rawat inap RSUD H. A. Sulthan Dg Radja Kabupaten Buukumba

\begin{tabular}{lcc}
\hline Tingkat Stres & F & \% \\
\hline Ringan & 54 & 56,8 \\
Sedang & 41 & 43,2 \\
\hline Total & $\mathbf{9 5}$ & $\mathbf{1 0 0 , 0}$ \\
\hline
\end{tabular}

